\title{
STUDI PERTUMBUHAN BIBIT RUMPUT LAUT (Kappaphycus alvarezii) HASIL KULTUR JARINGAN DENGAN METODE LONGLINE BERBINGKAI DI BALAI BESAR PERIKANAN BUDIDAYA LAUT LAMPUNG
}

\author{
Suci Rachmawati ${ }^{1}$ dan Annur Ahadi Abdillah ${ }^{2 *}$ \\ ${ }^{1}$ Program Studi Akuakultur, Fakultas Perikanan dan Kelautan, Universitas Airlangga \\ ${ }^{2}$ Departemen Kelautan, Fakultas Perikanan dan Kelautan, Universitas Airlangga \\ Email korespondensi : annur.ahadi@fpk.unair.ac.id
}

\begin{abstract}
Seaweed is one of the important commodities of fishery products that have economic value. Farmers often use repetitive seeds from the same broodstock so that they have the potential to experience a decline in quality. So it is necessary to do a study of seaweed cultivation using tissue culture seedling with the long line method as an effort to develop seaweed farming. Seaweed (Kappaphycuz alvarezii) has an absolute growth of 138.61 grams, with a growth rate of $4.85 \%$. The growth of seaweed from tissue culture seedlings is better than the growth of conventional seedlings.
\end{abstract}

Keywords: Seaweed; Kappaphycuz alvarezii; growth; Long line method.

\begin{abstract}
ABSTRAK
Rumput laut merupakan salah satu komoditas penting hasil perikanan yang memiliki nilai ekonomis. Petani sering menggunakan bibit yang berulang-ulang dari sumber indukan yang sama sehingga berpotensi mengalami penurunan kualitas. Sehingga perlu dilakukan studi mengenai budidaya rumput laut menggunakan bibit hasil kultur jaringan dengan metode long line sebagai upaya pengembangan usaha budidaya rumput laut. Rumput laut (Kappaphycuz alvarezii) memiliki pertumbuhan mutlak 138,61 gram, dengan laju pertumbuhan $4,85 \%$. Pertumbuhan rumput laut dari bibit hasil kultur jaringan lebih baik dibandingkan dengan pertumbuhan dari bibit konvensional.
\end{abstract}

Kata Kunci : Rumput laut; Kappaphycuz alvarezii; Pertumbuhan; Metode Long line. 


\section{PENDAHULUAN}

Rumput laut merupakan salah satu komoditas penting hasil perikanan yang memiliki nilai ekonomis (Rahim, 2018). Kebutuhan rumput laut dunia yang semakin meningkat mendorong peningkatan usaha budidaya rumput laut (Rahim, 2018). Potensi rumput laut di Indonesia mempunyai prospek yang cukup cerah meskipun saat ini pemanfaatannya hanya pada jenis yang telah umum dikenal (Patang dan Yunarti, 2013)

Saat ini, rumput laut masih menjadi salah satu komoditas andalan untuk meningkatkan produksi perikanan budidaya di Indonesia (Rahim et al., 2015) Bahkan Kementrian Kelautan dan Perikanan menaikkan target produksi rumput laut yang sebelumnya pada tahun 2016 produksinya hanya mencapai 11 juta ton, di tahun 2017 ini akan dinaikkan menjadi 13,4 juta ton (KKP, 2017).

Rumput laut mempunyai fungsi baik secara langsung maupun tidak langsung. Fungsi secara langsung, rumput laut menyediakan makanan bagi ikan dan invertebrata terutama thallus muda (Rahim et al., 2016). Secara tidak langsung rumput laut digunakan dalam berbagai industri yaitu pangan, kosmetik, obat-obatan, pupuk, tekstil, kulit dan industri lainnya (Soenardjo, 2011)

Keberhasilan budidaya rumput laut sangat tergantung pada teknik budidaya yang tepat dan dengan metode budidaya yang sesuai. Metode budidaya yang dipilih hendaknya dapat memberikan pertumbuhan yang baik, mudah dalam penerapannya dan bahan baku yang digunakan murah serta mudah didapat.

Keberhasilan budidaya rumput laut sangat tergantung pada teknik budidaya yang tepat dan dengan metode budidaya yang sesuai. Penggunaan metode ini sangat dipengaruhi oleh kondisi lokasi budidaya dan kebiasaan para pelaku utama dalam melakukan budidaya rumput laut.

Salah satu metode budidaya rumput laut yang umum di Indonesia adalah Metode Long Line. Metode Long Line adalah cara membudidayakan rumput laut dikolom air dekat permukaan perairan dengan menggunakan tali yang dibentangkan. Tali ris dibentangkan dari satu titik ke titik yang lain, dalam bentuk lajur lepas atau terangkai dengan bantuan pelampung dan jangkar (Hernanto dkk., 2015).

Salah satu kendala dalam pengembangan budidaya rumput laut adalah keterbatasan bibit yang kontinyu dan berkualitas. Petani sering menggunakan bibit yang berulang-ulang dari sumber indukan yang sama sehingga berpotensi mengalami penurunan kualitas.

Kini, permintaan komoditas rumput laut, baik untuk ekspor maupun untuk perlakuan pasar domestik cukup menjanjikan. Namun, informsi tentang teknologi budidaya rumput laut yang baru berkembang dengan memanfaatkan bibit unggul belum tersebar secara merata di masyarakat. Sehingga perlu diperhatikan teknologi budidaya untuk meningkatkan hasil produksi dan dapat menunjang keberhasilan dalam kegiatan budidaya.

Berdasarkan dari permasalahan tersebut, sehingga perlu dilakukan studi mengenai budidaya rumput laut menggunakan bibit hasil kultur jaringan dengan metode long line sebagai upaya pengembangan usaha budidaya rumput laut yang merupakan salah satu tahap menuju kegiatan budidaya yang dapat meningkatkan devisa Negara.

\section{METODE PENELITIAN}

\section{Alat dan bahan}

Bibit rumput laut Kappaphucuz alvarezi yang digunakan berasal dari bibit hasil kultur jaringan dari BBPBL. Alat yang digunakan yaitu tali PE (Poly Ethylen), styrofoam, botol air mineral sebagai pelampung. Bibit awal yang digunakan sebesar 50 gram/thallus. 


\section{Metode}

Metode yang digunakan yaitu metode survei pada proses budidaya di perairan laut BBPBL Lampung. Budidaya rumput laut $K$. alvarezii yang dilakukan adalah metode long line berbingkai, yaitu metode apung yang seluruh konstruksinya tersusun atas tali PE (Polyethylene). Metode long line berbingkai dipilih karena konstruksi media budidaya yang kokoh sehingga tidak bergeser jika terkena ombak (Rukni, 2016). Jarak ikatan antar thallus $20 \mathrm{~cm}$.Budidaya dilakukan selama 30 hari.

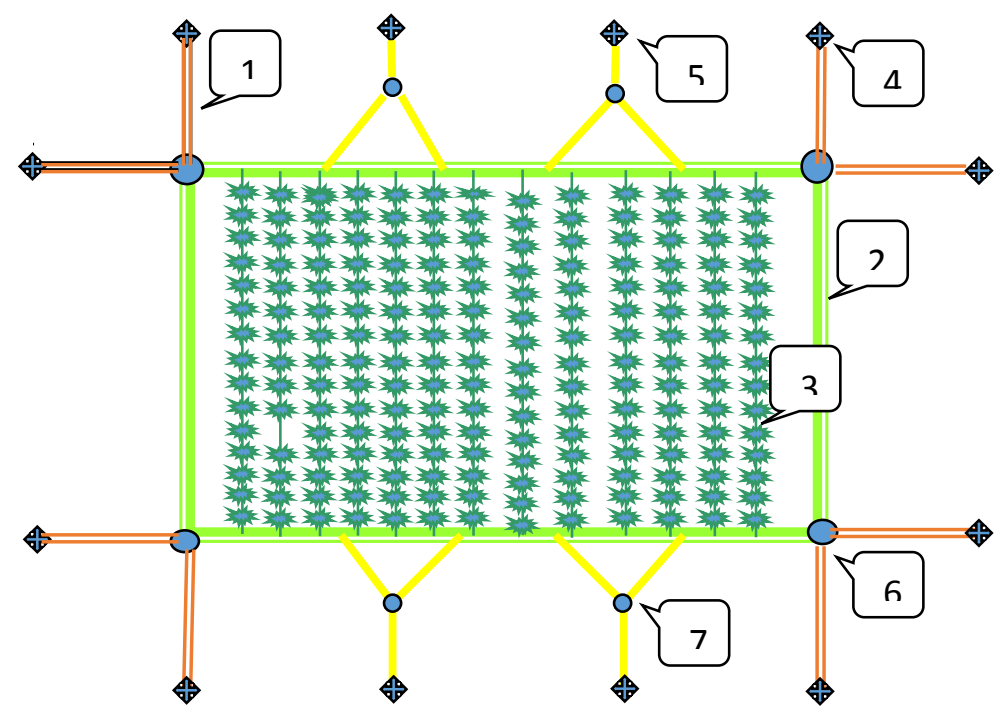

Keterangan:
1. Tali jangkar
5. Jangkar pembantu
2. Tali utama
6. Pelampung utama
3. Tali ris bentang
7. Pelampung pembantu
4. Jangkar utama

Gambar 1. Model konstruksi long line berbingkai

\section{Penyediaan Bibit}

Bibit utama yang digunakan di BBPBL adalah bibit yang diperoleh dari proses kultur jaringan, dimana bibit ini memiliki kualitas lebih baik dibandingkan dengan bibit konvensional. Sebelum ditanam ke laut, bibit terlebih dahulu diaklimatisasi. Bibit dikultur di laboratorium dengan tahap antara lain aklimatisasi indukan, sterilisasi eksplan, induksi kalus menggunakan hormon, regenerasi kalus menjadi rumput laut muda. Bibit rumput laut yang dikultur di laboratorium diberi perlakuan dengan pupuk PES $1 \mathrm{ml}$.

Bibit rumput laut yang sudah dikultur di laboratorium diaklimatisasi di green house. Bibit tersebut merupakan rumput laut muda berumur 3 bulan dengan panjang thallus $4-5 \mathrm{~cm}$ dan diameter thallus $2-3 \mathrm{~cm}$. Bibit tersebut dipelihara dalam akuarium berukuran $90 \mathrm{~cm}$ x $30 \mathrm{~cm}$ x $35 \mathrm{~cm}$ selama satu bulan dengan sistem sirkulasi air dan dilengkapi dengan aerator. Setiap tujuh hari sekali dilakukan pergantian air dan pemberian pupuk conwey. Aklimatisasi bertujuan untuk mengadaptasikan rumput laut dengan air laut dimana akan menjadi calon lingkungan budidayanya. Menurut Fadilah (2015), media air laut diberi aerasi kuat agar thallus rumput laut dapat lebih mudah menyerap nutrisi. Setelah satu bulan diaklimatisasi, bibit siap ditanam di lokasi yang telah ditentukan. 


\section{Persiapan Konstruksi Long line Berbingkai}

Penempatan konstruksi long line berbingkai di lokasi budidaya diawali dengan menyiapkan bahan-bahan yang akan digunakan, meliputi: jangkar, tali jangkar, tali utama/frame, pelampung utama dan pelampung pembantu yang diangkut dengan menggunakan speed boat atau perahu

\section{Pengikatan dan Penanaman Bibit}

Bibit yang akan ditanam terlebih dahulu dicuci untuk menghilangkan kotoran atau lumut yang menempel pada thallus dan disortir untuk memilih bibit yang baik untuk ditanam. Bibit yang sudah disortir sesuai berat yang diinginkan dengan menggunakan pisau atau gunting, diikatkan pada tali jalur yang telah dilengkapi dengan tali pengikat rumput laut. Berat bibit yang ditanam yaitu 50 gram per ikatan dengan jarak tanam antar titik tali $20 \mathrm{~cm}$.

\section{Sampling Pertumbuhan}

Kegiatan sampling dilakukan untuk mengetahui pertumbuhan rumput laut yang ditanam selama satu periode penanaman. Sampling dilakukan setiap seminggu sekali dengan cara melakukan penimbangan berat pada rumput laut yang menjadi sampel untuk mempermudah perhitungan dan analisis pertumbuhan rumput laut yang dibudidayakan. Sampel yang diambil berjumlah 10 thallus rumput laut.

\section{Sampling Kualitas Air}

Sebagai penunjang, dilakukan sampling kualitas air. Kualitas Air yang diamati terdiri dari Suhu, Kecerahan, Arus Air, Salinitas, pH, Nitrat dan Fosfat.

\section{HASIL DAN PEMBAHASAN}

\section{Pertumbuhan Berat}

Hasil pengamatan pertumbuhan rerata berat rumput laut disajikan pada gambar 2 .

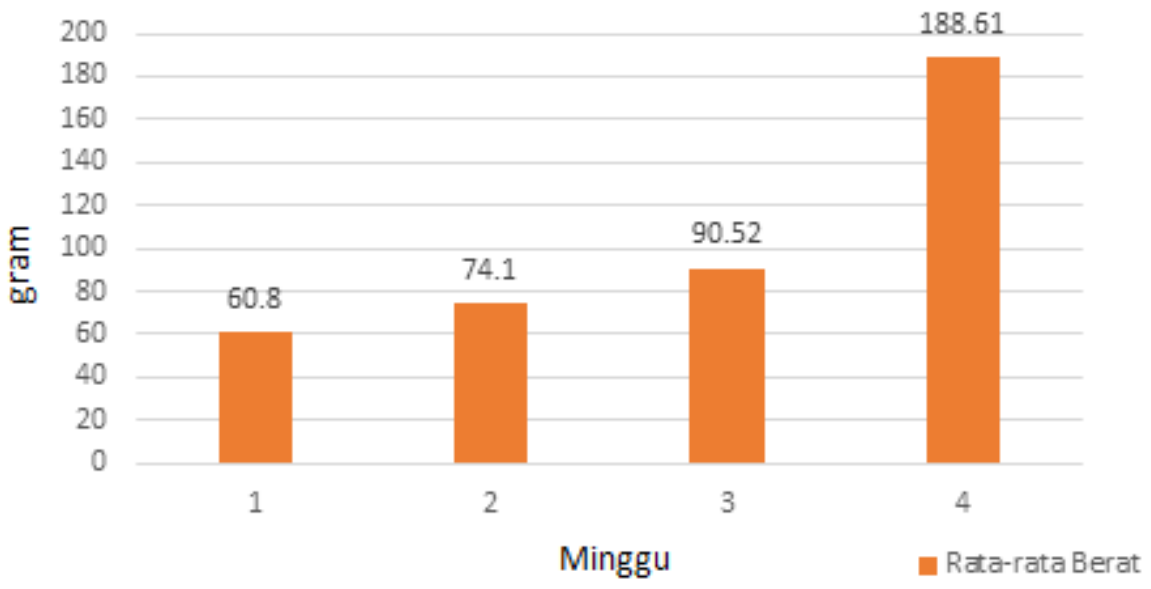

Gambar 2. Grafik pertumbuhan berat rerata rumput laut

Minggu pertama pertumbuhan rumput laut tumbuh menjadi 60,8 gram. Pada aminggu pertama pertumbuhan rumput laut tidak berbeda jauh dari berat awal. Hal ini karena bibit yang baru pertama kali ditanam di lokasi budidaya sedang melakukan adaptasi pada kondisi asli lingkungan dan dalam proses penyembuhan luka akibat potongan saat pemotongan bibit. 


\section{Pertumbuhan Mutlak}

Pertumbuhan mutlak adalah pertambahan berat (gram) rumput laut dengan menghitung selisih antara berat akhir dengan berat awal. Hasil perhitungan pertumbuhan rumput laut $K$. alvarezii dengan rata-rata berat tanam awal 50 gram/rumpun diperoleh nilai pertumbuhan mutlak sebesar 138,61 gram.

Dibandingkan dengan pernyataan tersebut, hal ini tidak sesuai dengan Runtuboy dkk. (2010), yang menyatakan bahwa kisaran pertumbuhan mutlak di wilayah Lampung dengan berat awal 50 gram dan lama pemeliharaan 30 hari sebesar 350-470 gram. Pertumbuhan mutlak yang diperoleh tidak lebih baik, karena diduga penanaman dilakukan tidak sesuai dengan musim tanam yang tepat. Sedangkan musim tanam yang tepat yakni bulan januari sampai agustus. Data pertumbuhan mutlak dapat dilihat pada tabel 1 .

Tabel 1. Pertumbuhan Mutlak

\begin{tabular}{|c|c|c|c|}
\hline No & $\begin{array}{c}\text { Berat Awal } \\
\text { (gram) }\end{array}$ & $\begin{array}{c}\text { Berat Akhir } \\
\text { (gram) }\end{array}$ & $\begin{array}{c}\text { Pertumbuhan Mutlak } \\
\text { (gram) }\end{array}$ \\
\hline 1 & 50 & 191,4 & 141,4 \\
\hline 2 & 50 & 186,7 & 136,7 \\
\hline 3 & 50 & 188,2 & 138,2 \\
\hline 4 & 50 & 179,8 & 129,8 \\
\hline 5 & 50 & 185,3 & 135,3 \\
\hline 6 & 50 & 180,2 & 130,2 \\
\hline 7 & 50 & 179,6 & 129,6 \\
\hline 8 & 50 & 207,5 & 157,5 \\
\hline 9 & 50 & 200,3 & 150,3 \\
\hline 10 & 50 & 187,1 & 137,1 \\
\hline Rata-rata & 50 & 188,61 & 138,61 \\
\hline
\end{tabular}

\section{Laju Pertumbuhan Harian}

Laju pertumbuhan harian merupakan perbandingan berat awal rumput laut dengan berat akhir rumput laut setiap harinya. Dari hasil pemeliharaan diperoleh laju pertumbuhan harian(LPH) rumput laut Kappaphycus alvarezii dengan metode long line berbingkai yang disajikan pada gambar 3 .

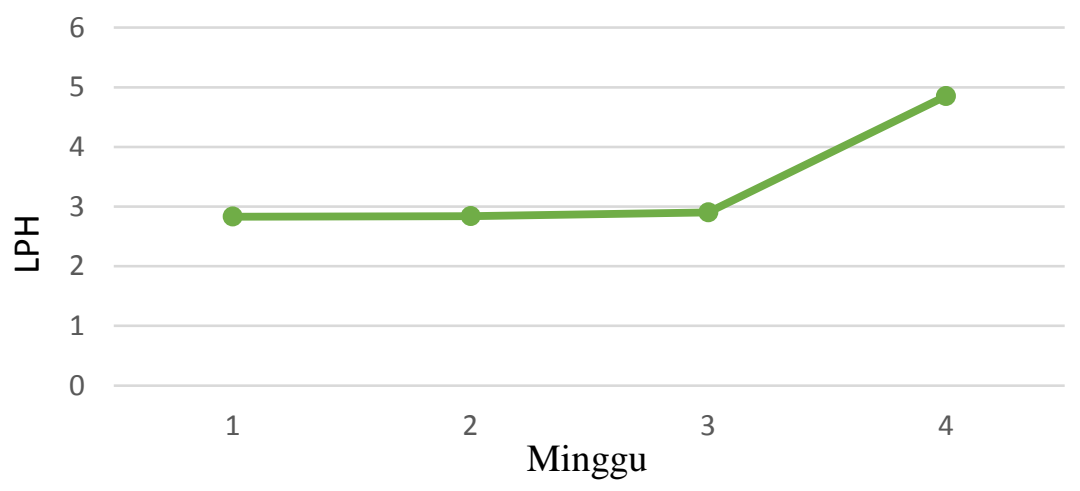

Gambar 3. Grafik laju pertumbuhan rumput laut 
Laju pertumbuhan harian rumput laut Kappaphycus alvarezii dari minggu pertama hingga minggu keempat terus mengalami kenaikan. Dimulai dari minggu pertama tingkat laju pertumbuhan harian sebesar $2,83 \%$ dan selanjutnya pada minggu kedua yang mengalami kenaikan hanya sedikit dari minggu pertama yaitu $2,84 \%$ dan pada minggu ketiga 2,9\%. Namun pada minggu keempat mengalami kenaikan yang lebih banyak menjadi $4,85 \%$.

Laju pertumbuhan rumput laut sekitar 4,85\% tiap hari yang menunjukkan pertumbuhan rumput laut cukup bagus. Rumput laut dengan bibit konvensional dalam laporan Abdullah (2011) memiliki laju pertumbuhan 4,546\% tiap hari dengan pemanenan 30 hari. Namun, Lym Yong et al., (2014) menyatakan bahwa laju pertumbuhan $K$. alvarezii hasil kultur jaringan mencapai 6,3\% tiap hari.

Asumsi terjadinya laju pertumbuhan yang tidak maksimal ini adalah karena cuaca yang tidak mendukung selama masa pemeliharaan seperti fluktuasi suhu yang ekstrim akibat perubahan dari panas ke hujan dan sebaliknya dalam sehari . Pada saat suhu sangat tinggi secara tiba-tiba mengakibatkan thallus rumput laut menjadi pucat kekuningan yang menjadikan rumput laut tidak tumbuh dengan baik. Selain itu juga disebabkan rendahnya kecepatan arus pada perairan yang mengakibatkan sedimen atau kotoran yang menempel pada rumput laut tidak dapat terlepas sehingga menghalangi rumput laut memperoleh cahaya yang akan menunjang proses fotosintesis. Menurut Asni (2015), apabila salinitas rendah, maka rumput laut akan berwarna pucat, gampang patah dan lunak akhirnya membusuk serta tidak tumbuh dengan normal dan mati.

Rendahnya proses fotosintesis tidak akan merangsang rumput laut untuk menyerap unsur hara yang lebih banyak yang akan menunjang pertumbuhan. Arus air sangat berperan dalam perolehan nutrien bagi rumput laut karena arus berperan penting bagi penyediaan nutrien dalam perairan (Asni, 2015).

Sebaliknya pada minggu keempat laju pertumbuhan meningkat yaitu $4,85 \%$ /hari tergolong pertumbuhan yang baik karena melebihi $3 \%$. Hal ini dikarenakan pada saat setelah minggu ketiga, warna rumput laut yang telah memucat dan kekuningan berubah menjadi segar dan spesifik kembali karena cuaca sudah mulai baik. Namun laju pertumbuhan harian rumput laut Kapapphycus alvarezii masih rendah jika dibandingkan dengan hasil kultur jaringan Lym Yong, et al, (2014) yang mencapai 6,3\% per hari.

Laju pertumbuhan rumput laut dipengaruhi oleh dua faktor yaitu faktor eksternal dan faktor internal. Faktor internal antara lain jenis, galur, bagian thallus, dan umur. Sedangkan faktor eksternal antara lain keadaan lingkungan fisik dan kimiawi perairan. Selain faktor-faktor tersebut, ada faktor lain yaitu faktor pengelolaan yang dilakukan oleh manusia. Faktor pengelolaan oleh manusia dalam kegiatan rumput laut kadang merupakan faktor utama yang harus diperhatikan seperti jarak tanam bibit.

\section{Parameter Kualitas Air}

Hasil pengukuran parameter kualitas air selama pemeliharaan dapat dilihat pada tabel 2.

\begin{tabular}{|c|c|c|c|c|c|c|c|}
\hline No & Parameter & Satuan & $\begin{array}{c}\text { Minggu } \\
\text { Ke-1 }\end{array}$ & $\begin{array}{c}\text { Minggu } \\
\text { Ke-2 }\end{array}$ & $\begin{array}{c}\text { Minggu } \\
\text { Ke-3 }\end{array}$ & $\begin{array}{c}\text { Minggu } \\
\text { Ke-4 }\end{array}$ & Pustaka \\
\hline 1 & Suhu & ${ }^{\circ} \mathrm{C}$ & 27,6 & 28,32 & 28,48 & 28,2 & $28-30$ \\
\hline 2 & Kecerahan & $\mathrm{m}$ & 6 & 5 & 6 & 6 & $>5$ \\
\hline 3 & Arus & $\mathrm{cm} / \mathrm{s}$ & 12 & 8,4 & 8,6 & 9,8 & $20-40$ \\
\hline
\end{tabular}




\begin{tabular}{|c|c|c|c|c|c|c|c|}
4 & Salinitas & $\mathrm{ppt}$ & 33 & 33 & 32 & 32 & $32-34$ \\
\hline 5 & $\mathrm{pH}$ & - & 7,059 & 7 & 7,174 & 7 & $7-8,5$ \\
\hline 6 & Nitrat & $\mathrm{mg} / \mathrm{L}$ & 2,823 & 1,128 & 1,884 & 1,325 & $0,9-3,0$ \\
\hline 7 & Fosfat & $\mathrm{mg} / \mathrm{L}$ & 0,958 & 1,136 & 0,629 & 0,819 & $\begin{array}{c}0,05- \\
1,00\end{array}$ \\
\hline
\end{tabular}

Tabel 2. Hasil Pengukuran kualitas air

Suhu selama pemeliharaan berkisar antara $27-28^{\circ} \mathrm{C}$, kisaran suhu tersebut sudah cukup mendukung pertumbuhan rumput laut. Kisaran suhu yang baik untuk budidaya rumput laut adalah $20-30{ }^{\circ} \mathrm{C}$ (Sudradjat, 2015). Suhu perairan mempengaruhi beberapa hal yang terkait dengan kehidupan rumput laut, seperti kehilangan hidup, pertumbuhan dan perkembangan, reproduksi, fotosintesis, dan respirasi. Suhu perairan yang tinggi akan mengakibatkan thallus rumput laut pucat kekuningan yang menjadikan rumput laut tidak tumbuh dengan baik (Asni, 2015).

Pengukuran kecerahan secara umum di lokasi budidaya berkisar 5 - 6 meter. Nilai ini menunjukkan bahwa lokasi ini baik untuk budidaya Kappaphycus alvarezii, karena sesuai dengan nilai yang dipersyaratkan yaitu 2-5 meter (Sudradjat, 2015). Semakin cerah suatu perairan berarti partikel-partikel lumpur yang kemungkinan terdapat dalm kolom air semakin sedikit, sehingga memungkinkan cahaya yang masuk ke perairan semakin besar, yang selanjutnya intensitas cahaya yang besar akan menunjang proses fotosintesis rumput laut. Peningkatan proses fotosintesis akan menyebabkan proses metabolisme sehingga merangsang rumput laut untuk menyerap unsur hara yang lebih banyak, penyerapan unsur hara yang lebih banyak akan menunjang pertumbuhan.

Kecepatan arus di lokasi budidaya rata-rata berkisar $8-12 \mathrm{~cm} /$ detik. Menurut Sudradjat (2015), menyatakan bahwa kecepatan arus yang baik untuk budidaya rumput laut adalah 20-40 cm/detik. Arus merupakan salah satu faktor penting dalam pertumbuhan rumput laut. Hal ni dikarenakan arus mempunyai peranan penting dalam transportasi unsur hara sebagai sumber nutrien, gerakan air yang cukup akan menghindari terkumpulnya kotoran pada thallus, membantu mencegah adanya fluktuasi yang besar terhadap salinitas dan suhu.

Salinitas perairan selama pemeliharaan berkisar antara 32 - 33 ppt. K. alvarezii merupakan rumput laut yang tidak tahan terhadap kisaran kadar garam yang tinggi (stenohaline). Salinitas yang sesuai untuk pertumbuhan $K$. alvarezii berkisar 28-35 ppt (Sudradjat, 2015). Perubahan salinitas yang ekstrim dapat menyebabkan timbulnya penyakit ice-ice. Oleh karena itu untuk memperoleh perairan dengan salinitas tersebut, lokasi harus jauh dari sumber air tawar yaitu sungai kecil atau muara sungai. Apabila salinitas rendah, rumput laut akan berwarna pucat, mudah patah dan lunak akhirnya membusuk dn mati. Sedangkan salinitas air yag tinggi menyebabkan rumput laut menjadi pucat kekuningan yang menjadikan rumput laut tidak tumbuh dngan baik (Asni, 2015).

Pengukuran $\mathrm{pH}$ perairan selama pengamatan relatif stabil dan berada pada kisaran adaptasi bagi rumput yaitu berkisar antara 7 - 7,174. Menurut Sudradjat (2015) bahwa $\mathrm{pH}$ optimal bagi pertumbuhan $K$. alvarezii berkisar 7,3-8,2. Perubahan $\mathrm{pH}$ selama pemeliharaan relatif kecil karena perairan mempunyai sistem penyangga terhadap perubahan ion yang drastis (Asni, 2015). 
Hasil pengukuran rata-rata kadar nitrat yaitu 1,325 - 2,823 ppm. Kisaran yang didapatkan sudah cukup optimal untuk pertumbuhan rumput laut $K$. alvarezii yang membutuhkan kisaran nitrat sebesar 0,9-3,5 ppm (Fikri dkk., 2015). Kadar nitrat dan fosfat di perairan akan berpengaruh terhadap kesuburan gametofit alga. Nitrat (NO3) merupakan bentuk utama nitrogen di perairan alami dan merupakan nutrien bagi pertumbuhan rumput laut.

Kadar fosfat perairan di lokasi budidaya selama pemeliharaan masih dalam ambang batas yang layak dalam menunjang pertumbuhan rumput laut yaitu berkisar 0,629 - 1,136 ppm. Fosfat merupakan bentuk fosfor yang dapat dimanfaatkan oleh rumput laut. Karakteristik fosfor sangat berbeda dengan unsur-unsur utama lain yang merupakan penyusun biosfer karena unsur ini tidak terdapat di atmosfer. Fosfat dapat menjadi faktor pembatas karena sumber fosfat yang sedikit di perairan dan merupakan salah satu unsur hara yang penting bagi metabolisme tanaman. Menurut Poncomulyo dkk. (2008) kisaran fosfat yang optimal untuk pertumbuhan rumput laut adalah 0,051 $1,00 \mathrm{mg} / \mathrm{l}$.

\section{KESIMPULAN DAN SARAN}

Rumput laut (Kappaphycuz alvarezii) memiliki pertumbuhan mutlak 138,61 gram, dengan laju pertumbuhan $4,85 \%$. Pertumbuhan rumput laut dari bibit hasil kultur jaringan lebih baik dibandingkan dengan pertumbuhan dari bibit konvensional

\section{DAFTAR PUSTAKA}

Abdullah, A.A. 2011. Teknik Budidaya Rumput Laut Kappaphys alvarezii dengan Metode Rakit Apung di esa Tanjung, Kecamatan Saronggi, Kabupaten Sumenep, Jawa Timur. Jurnal Ilmiah Perikanan dan Kelautan. Vol.3, No.1.

Asni, A. 2015.Analisis Produksi Rumput Laut (Kappaphycus alvarezii) Berdasarkan Musim dan Jarak Lokasi Budidaya Diperairan Kabupaten Bantaeng. Jurnal Akuatik. Vol. 6, No. 2: 145-148.

Fadilah,S. 2015. Teknologi Produksi Bibit Rumput Laut Gracilaria gigas dengan Metode Kultur Jaringan. Loka Penelitian dan Pengembangan Budidaya Rumput Laut. Boalemo.

Fikri, M., Rejeki, S. dan Widowati, LL. 2015. Produksi dan Kualitas Rumput Laut (Eucheuma cottonii) dengan Kedalaman Berbeda di Perairan Bulu Kabupaten Jepara. Journal of Aquaculture Management and Technology. Vol. 4, No. 2: $67-74$.

Hernanto, A.D., Sri Rejeki, dan Restiana W.A. 2015. Pertumbuhan Budidaya Rumput Laut (Eucheuma cottonii dan Gracilaria sp.) dengan Metode Longline di Perairan Pantai Bulu Jepara. Journal of Aquaculture Management and Technology. Vol.4, No.2: 60-66.

KKP. 2017. Kelautan dan Perikanan Dalam Angka. Kementrian Kelautan dan Perikanan.

Lym Yong, W.T., J.Y Yung Chin, V.Y. Thien and S. Yasir. 2014. Evaluation of Growth Rate and Semirefined Carrageenan Properties of Tissue-Cultured Kappaphycus alvarezii (Rhodophyta, Gigartinales). Phycological Research Volume 62, Issue 4, pages 316-321.

Patang dan Yunarti. 2013. Pengaruh Berbagai Metode Budidaya dalam Meningkatkan Produksi Rumput Laut Kappaphycus alvarezii (Kasus di Kecamatan Mandalle Kabupaten Pangkep). Jurnal Galung Tropika. Vol. 2, No. 2: 60-63.

Poncomulyo, T., H. Maryani., L. Kristiani. 2006. Budidaya dan Pengolahan Rumput Laut. Agromedia. Jakarta. hal. $14-15$. 
Rahim, A. R., Herawati, E. Y., Nursyam, H., Hariati, A. M. 2015. Cells Characteristics, Growth, and Quality of Gracilaria verrucosa Seaweed Production with Different Doses of Vermicompost Fertilizer. International Journal of Science Technology and Engineering, Volume 2, Issue 1.

Rahim, A. R., Herawati, E. Y., Nursyam, H., Hariati, A. M. 2016. Combination of Vermicompost Fertilizer, Carbon, Nitrogen and Phosphorus on Cell Characteristics, Growth and Quality of Agar Seaweed Gracilaria verrucosa. Nature Environment \& Pollution Technology, 15(4).

Rahim, A. R. 2018. Application of Seaweed Gracilaria verrucosa Tissue Culture using Different Doses of Vermicompost Fertilizer. Nature Environment and Pollution Technology, 17(2), 661-665.

Rahim, A. R. 2018. Utilization of Organic Wastes for Vermicomposting Using Lumbricus rubellus in Increasing Quality and Quantity of Seaweed Gracilaria verrucosa. Asian Journal of Microbiology, Biotechnology and Environmental Sciences. Volume 20, No. 2: 2018: S17 - S23.

Runtuboy, N., Tiya Widi A., dan Slamet A. 2008. Teknik Budidaya Rumput Laut Kappaphycus alvarezii. Departemen Kelautan dan Perikanan, Direktorat Jenderal Perikanan Budidaya, Balai Besar Perikanan Budidaya Laut, Lampung.

Soenardjo, N. 2011. Aplikasi Budidaya Rumput Laut Eucheuma cottoni (Weber Van Bosse) dengan Metode Jaring Lepas Dasar (Net Bag) Model Cidaun. Buletin Oseanografi Marina Vol. 1 hal 36-44, Edisi Oktober 2011.

Sudradjat, A. 2015. Budidaya Ko15. Budidaya 26 Komoditas Laut Unggul. Penebar Swadaya. Jakarta. 